\title{
FUSARIUM HEAD BLIGHT OF WINTER RYE (Secale cereale $\mathrm{L}$.
}

\author{
Irena Kiecana, Elżbieta Mielniczuk
}

\begin{abstract}
Department of Phytopathology, University of Life Sciences in Lublin, Leszczynskiego 7, 20-069 Lublin, Poland, e-mail: irena.kiecana@up.lublin.pl
\end{abstract}

Received: 27.11.2009

\section{Abstract}

Investigations on Fusarium head blight of rye were carried out in the years 2005-2007 on 10 production fields in the Lublin region. The percentage of heads showing the fusariosis symptoms in the years 2005-2007 ranged from 0 to $7 \%$.

Mycological analysis of kernels and chaff obtained from heads with Fusarium blight (scab) symptoms showed that Fusarium avenaceum, Fusarium culmorum and Fusarium sporotrichioides were the largest threat to heads of this cereal. The species of Fusarium poae and Fusarium crookwellense were also isolated from infected rye heads. The dominance of particular species in infecting rye heads was determined by weather conditions.

Key words: Fusarium avenaceum, F. culmorum, F. sporotrichioides, head blight, winter rye

\section{INTRODUCTION}

Fusarium head blight is a dangerous disease of cereals cultivated in different climatic zones ( $\mathrm{Ki} \mathrm{e}$ cana, 1994; B ottalico, 1998; B ottalico and Perrone, 2002; Šrobarová et al. 2008; Muthomi et al. 2008). The first reports on scab of rye come from Canada from the 1950's. The species of $F$. avenaceum, $F$. culmorum, $F$. graminearum, $F$. poae and $F$. sporotrichioides were found to be the main cause of this disease (Parry et al. 1995; B ottali co, 1998; P a n i s s on et al. 2003). For rye grown in Poland and Germany, F. culmorum and $F$. graminearum have a considerable importance in causing fusariosis of rye heads (K i e c a n a, 1988; M i edane r et al. 2001; 2003). Among other species from the genus of Fusarium, some studies found the presence of $F$. avenaceum, $F$. poae and $F$. sporotrichioides as well as Microdochium nivale on infected heads of rye in our country (K i e cana, 1988; Chełk ow ski, 1989; Wakuliński and Chełkowski, 1993).
By infecting heads and kernels of cereals, $F u$ sarium spp. cause not only a decrease of the yield, but they are also dangerous to homoithermic organisms because the latter produce toxic metabolites in the infected kernels and these include trichothecene compounds, zearelenon, moniliformin and many others (Miedaner et al. 2001; 2003; B ottalico and Perrone, 2002).

Due to the lack of reports in phytopathological literature of recent years on Fusarium spp. colonizing rye heads and because of the common occurrence of toxin-producing species from the genus of Fusarium on other cereals, studies were undertaken on Fusarium head blight of rye grown in the Lublin region.

\section{MATERIALS AND METHODS}

The studies were carried out in the years 20052007 on 10 production plantations of winter rye (Secale cereale L.) cv. Dańkowskie Złote which were situated in the Lublin region (two in each of the following localities: Wola Sernicka (plantations 1, 2), Brzostówka (plantations 3, 4), Wólka Zabłocka (plantations 5, 6), Uścimów (plantations 7, 8) and Głębokie (plantations 9, 10) (Fig. 1).

In each year of the study, the percentage of heads with fusariosis symptoms of was determined at the stage of full maturity of kernels (92 in Tottman's scale, 1987). Following the pattern of studies on spring barley (K i e c a n a, 1994), 400 heads (100 heads from each site of particular plantations) were analyzed from each field.

Next, 20 heads infected by Fusarium spp. were taken for laboratory analysis from each of the studied plantations.

100 kernels and 100 chaff from the heads, from each plantation, were taken for mycological analysis. 
A mineral medium (Łacicowa, 1970) was used for the isolation of fungi from the plant material. The method of conducting the analysis was like that in the study by Mi e ln ic z u k (2001).

Fungi from the genus of Fusarium were identified using the keys by $\mathrm{Nels}$ on et al. (1983) and B u rge s s et al. (1988). Other species were identified according to the keys and monographs by $\mathrm{Ki}$ e $\mathrm{c} \mathrm{an} \mathrm{a}$ et al. (2009).

The information concerning the weather conditions during the investigations was obtained from the Department of Agrometeorology, University of Life Sciences in Lublin.

\section{RESULTS}

Field observations carried out at the stage of full maturity of kernels in rye sown on the plantations of the Lublin region pointed to the occurrence of plants with fusariosis symptoms on the heads. In all the plantations, the heads were diminished, whereas on chaff there was visible an orange-rosy powder, especially at the points of contact with the rachis, which consisted of the mycelium and spores of Fusarium spp. The kernels from the infected heads were usually smaller and of white-greyish colour. In 2005 the percentage of heads showing fusariosis symptoms ranged from 0 to 5 , in 2006 from 0 to 0.5, and in 2007 from 1 to 7 (Fig. 1).

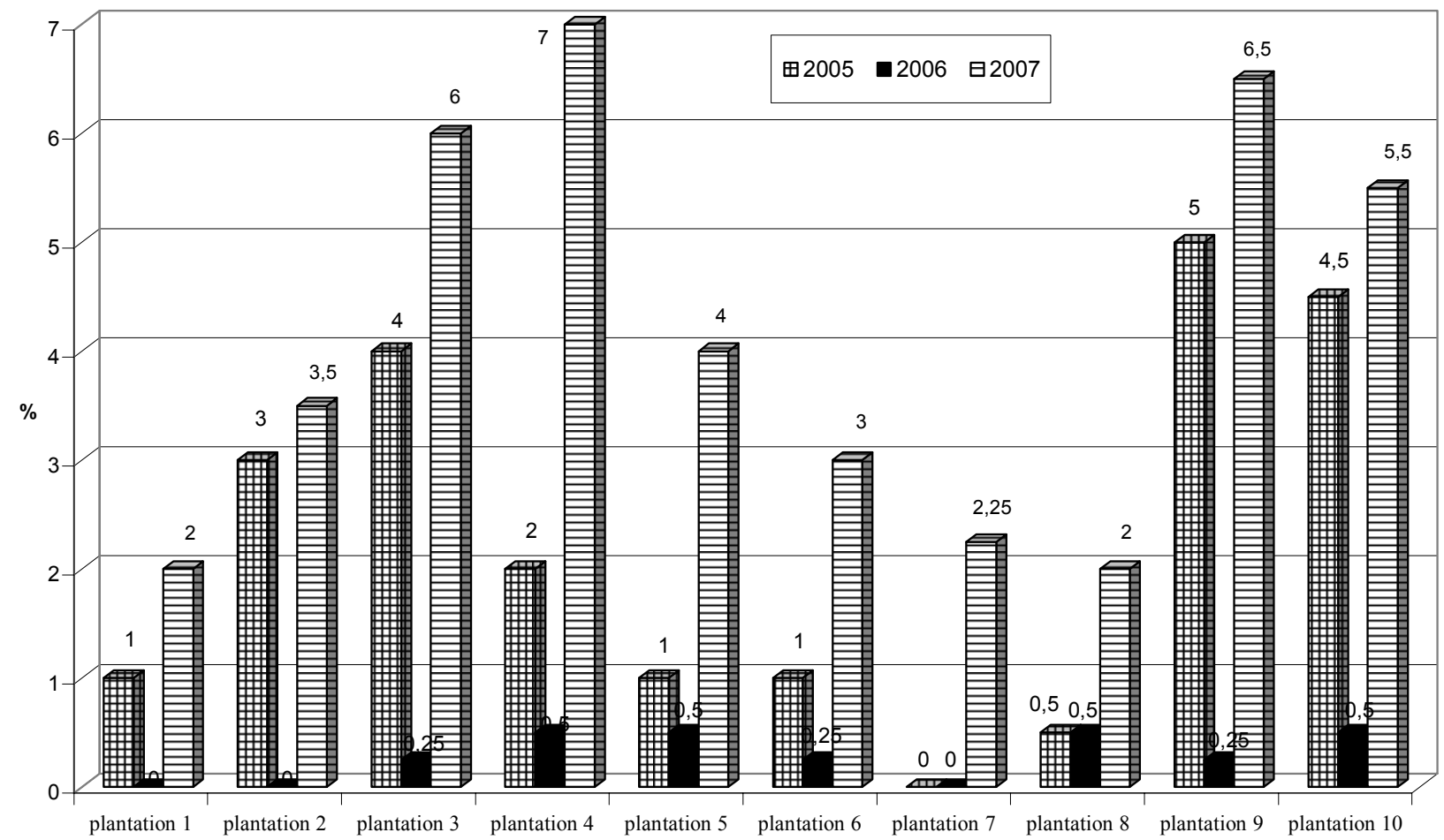

Fig. 1. Percentage of rye heads with fusarium head blight symptoms in the years 2005-2007

As a result of mycological analysis of kernels from the heads with the disease symptoms, over the 3 years of the study 2837 colonies of fungi were isolated, while 929 isolates were obtained from chaff (Table 1). In the years 2005, 2006 and 2007 Fusarium spp. colonies amounted to, respectively, $33 \%, 41 \%$ and $21 \%$ of all fungal isolates from kernels, whereas isolates from chaff accounted for $41 \%$ (2005), 23\% (2006) and $48 \%$ (2007), and they were represented by: $F$. avenaceum, $F$. crookwellense, $F$. culmorum. F. poae and $F$. sporotrichioides (Table1). Regardless of the vegetation season, the species of $F$. avenaceum and $F$. culmorum distinguished themselves by causing general infection of heads. During the study years, $F$. avenaceum isolates amounted from $35.7 \%$ (2005) to $42.5 \%$ (2007), whereas isolates of F. culmorum from $25.8 \%$ (2006) to $29.2 \%$ (2005) of all Fusarium spp. from kernels (Fig. 2). In the case of chaff, $F$. avenaceum isolates amounted from $33.3 \%$ (2005) to $47.7 \%$ (2006), whereas F. culmorum from $30.0 \%$ (2007) to $37.8 \%$ (2005) of all Fusarium spp. from chaff (Fig. 3).

Besides, in each year of the study, the species of $F$. sporotrichioides were frequently obtained from infected kernels, and their isolates amounted from $11.4 \%$ of total Fusarium spp. from kernels in 2007 up to $27.0 \%$ in 2006 (Fig. 2). On the other hand, in the case of chaff, the colonies of this fungus constituted from $13.6 \%$ to $24.1 \%$ of all Fusarium spp. (Fig. 3). The proportion of $F$. crookwellense and $F$. poae in the years in question ranged, respectively, from $2.9 \%$ to 
$8.7 \%$ and from $5.6 \%$ to $9.6 \%$ of all isolates from kernels (Fig. 2), and from $0 \%$ to $1.8 \%$, and from $1.8 \%$ to $7.1 \%$ of total colonies from chaff (Fig. 3).

Isolates of other fungi belonged to the following: Alternaria alternata $(37.68 \%$ of all isolates from kernels and chaff over the 3 years of the study),
Aspergillus flavus (0.16\%), Bipolaris sorokiniana $(0.21 \%)$, Botrytis cinerea $(0.27 \%)$, Chaetomium globosum (0.24\%), Cladosporium cladosporioides (3.24\%), Epicoccum nigrum (23.74\%), Penicillium verrucosum var. cyclopium $(0.21 \%)$ as well as nonsporulating forms $(1.3 \%)$ (Table 1$)$.

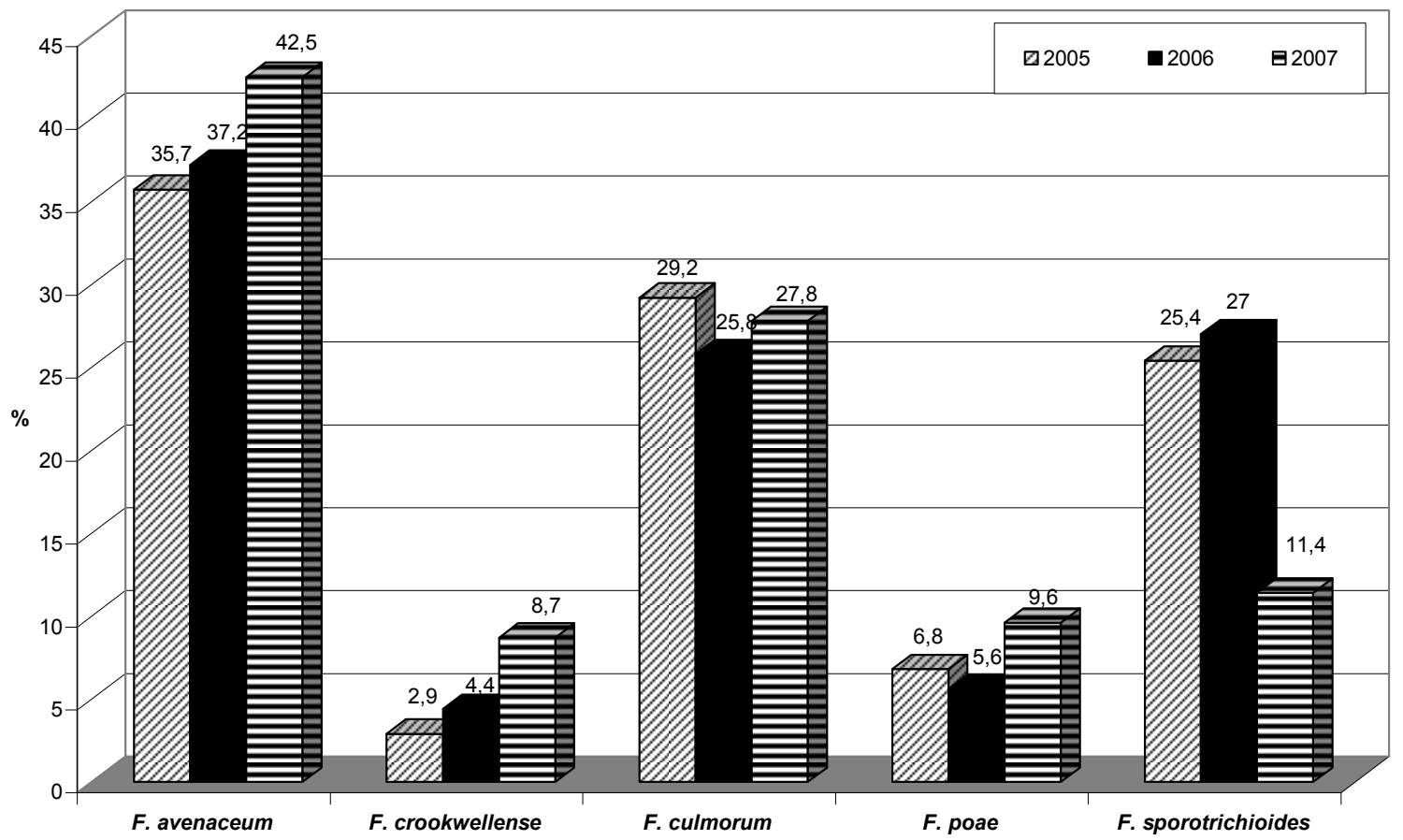

Fig. 2. The proportion of individual species in all Fusarium spp. isolates obtained from rye kernels in the years 2005,2006 and 2007

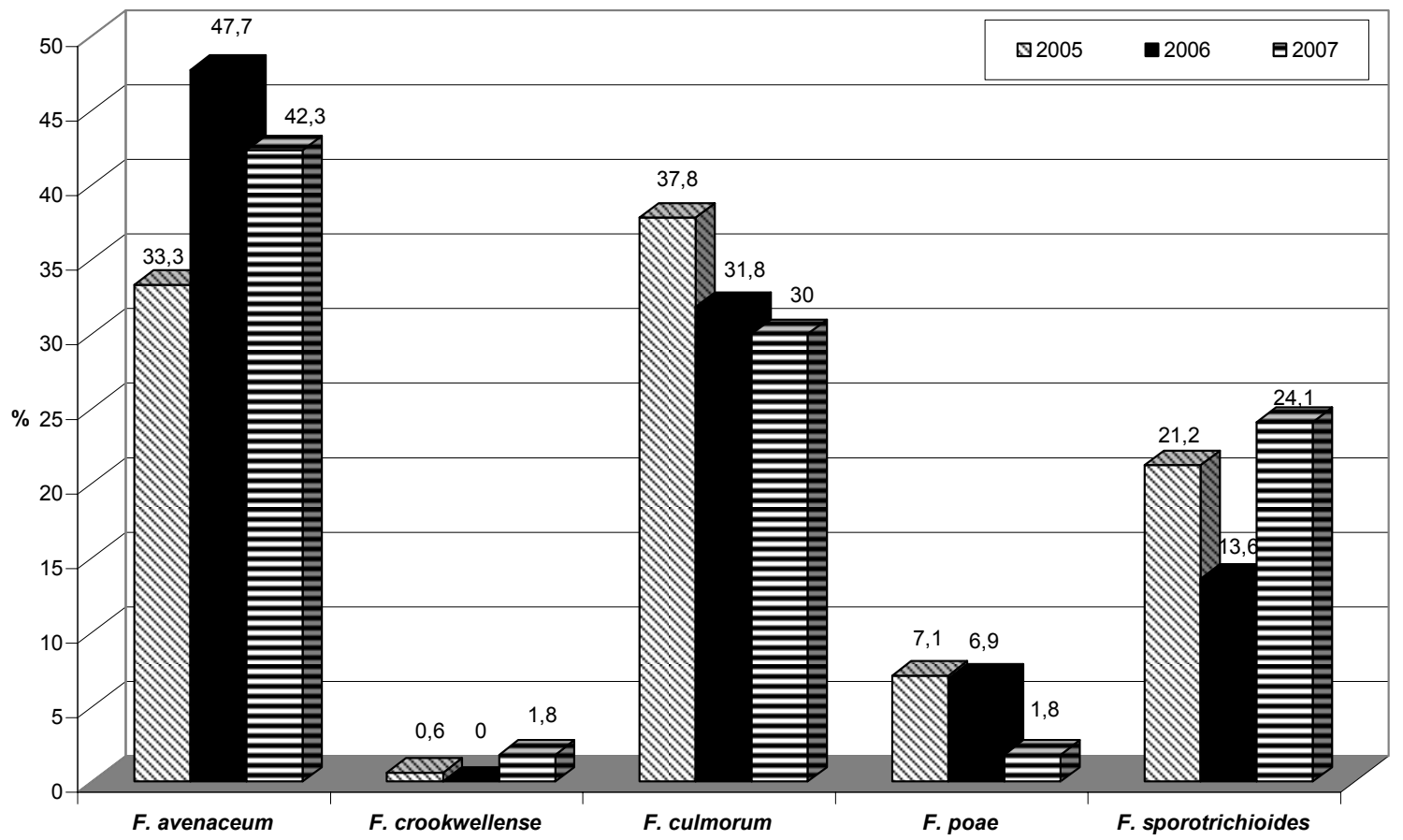

Fig. 3. The proportion of individual species in all Fusarium spp. isolates obtained from rye chaff in the years 2005,2006 and 2007 


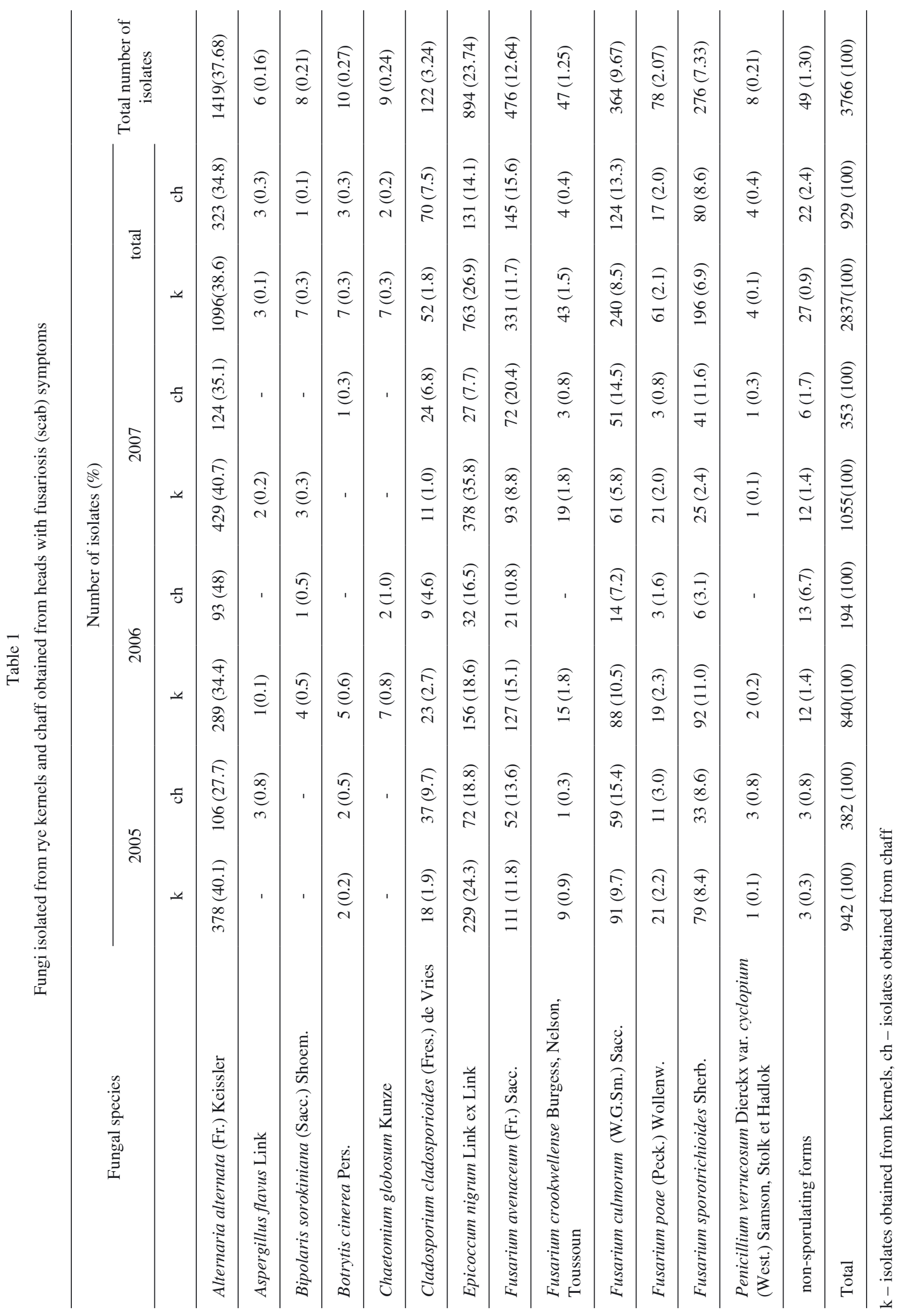


The temperature in the Lublin region during the 2005 growing season (the period of heading, flowering and grain maturation of winter rye) was higher as compared to the long-term means in months of April, May and July from $0.2^{\circ} \mathrm{C}$ to $2.1^{\circ} \mathrm{C}$, while in June air temperature was about $0.4^{\circ} \mathrm{C}$ lower compared to the long-term means. On the other hand, rainfall exceeded the longterm means in May and July by, respectively, $67.52 \%$ and $41.13 \%$. The lowest rainfall was recorded in April of that year - only $47.94 \%$ of the normal level. In 2006 air temperature between April and July was higher than the long-term mean by $0.5^{\circ} \mathrm{C}$ (June) to $4.2 \%{ }^{\circ} \mathrm{C}$ (July). The percentage of normal rainfall ranged from 8.74 in June to 269.06 in July. In 2007 air temperature was higher than the long-term mean by $1.3^{\circ} \mathrm{C}$ in April to $2.0^{\circ} \mathrm{C}$ in May. On the other hand, rainfall exceeded the long-term mean in May, June and July, respectively, by $37.61,29.31$ and $11.82 \%$. The lowest amount of rainfall was observed in April of $2007-44.84 \%$ of the normal level (Table 2).

Table 2

Air temperature and rainfall in the growing season - in the period of heading, flowering and grain maturation of winter rye, in the years 2005-2007

\begin{tabular}{|c|c|c|c|c|c|c|c|c|}
\hline \multirow[t]{2}{*}{ Month } & \multicolumn{2}{|c|}{ Mean for 1951-1990 } & \multicolumn{3}{|c|}{$\begin{array}{l}\text { Air temperature difference compared } \\
\text { with the mean for } 1951-1990 \\
{\left[{ }^{0} \mathrm{C}\right]}\end{array}$} & \multicolumn{3}{|c|}{$\begin{array}{c}\text { Percentage of rainfall compared with } \\
\text { the mean for } 1951-1990 \\
{[\%]}\end{array}$} \\
\hline & $\begin{array}{c}\text { Air temperature } \\
{\left[{ }^{0} \mathrm{C}\right]}\end{array}$ & $\begin{array}{c}\text { Rainfall } \\
{[\mathrm{mm}]}\end{array}$ & 2005 & 2006 & 2007 & 2005 & 2006 & 2007 \\
\hline April & 7.4 & 38.8 & +1.7 & +1.3 & +1.3 & 47.94 & 101.71 & 44.84 \\
\hline May & 13.0 & 58.5 & +0.2 & +0.6 & +2.0 & 167.52 & 55.82 & 137.61 \\
\hline June & 16.4 & 67.9 & -0.4 & +0.5 & +1.7 & 82.33 & 8.74 & 129.31 \\
\hline July & 17.7 & 73.7 & +2.1 & +4.2 & +1.5 & 141.13 & 269.06 & 111.82 \\
\hline
\end{tabular}

\section{DISCUSSION}

The results of the study carried out in the years 2005-2007 show that Fusarium head blight of rye grown in the north-eastern part of the Lublin region occurred in each year of the study, with the proportion of infected heads not exceeding 7\%. The studies conducted in the conditions of the Lublin region indicate a similar frequency in the infection of triticale heads by fungi of the Fusarium genus (Kiecana, 1986), while this frequency was higher in the infection of wheat heads (Łacicowa et al. 1987) and oat panicles (Mielniczuk, 2001).

The studies show that the species of $F$. avenaceum, $F$. culmorum and $F$. sporotrichioides are the cause of rye scab, as in the case of other cereals (K i e c a n a, 1994; Mielniczuk, 2001; V a čo et al. 2007; Šrobarová et al. 2008). The proportions of particular species in infecting heads are determined by weather conditions (K i e c a n a, 1994; M i e ln i c z u k, 2001; Bottalico and Perrone, 2002; Xu et al. 2008).

The common occurrence of $F$. avenaceum on rye heads in each year of the study, varying from year to year, is explained by high tolerance of this fungus to temperature and humidity (K i e c a n a, 1994; M i e 1 niczuk, 2001; Kiecana et al. 2003; Xu et al. 2008).
The present authors' earlier studies showed that the species of $F$. avenaceum posed a threat to rye grown in the Lublin region, mainly due to its high harmfulness to seedlings of this cereal ( $\mathrm{K} \mathrm{i} \mathrm{e} \mathrm{c} \mathrm{a} \mathrm{n} \mathrm{a} \mathrm{et} \mathrm{al.} \mathrm{2009).}$

The present study confirmed that the infection of rye heads by $F$. culmorum - like in the case of barley heads and oat panicles - is favoured by hot weather with passing rainfalls (K i e c a n a , 1994; M i e lniczuk, 2001; Miedaner et al.1993; 2001). In the case of the present study, such weather conditions occurred in the years 2005 and 2007 and it is these conditions that account for a considerable proportion of the species under discussion in the infection of rye heads in these growing seasons.

It has been established that in Poland F. culmorum has a significant proportion in the infection of root and stem bases of rye ( $\mathrm{P}$ a ł y s et al. 2004; K i e c a n a et al. 2009).

In 2007 the species of $F$. crookwellense, besides $F$. culmorum, occurred on rye heads with greater frequency as compared to the other years. It should be supposed that weather conditions conducive to the development of this fungus are similar to the requirements of $F$. culmorum as far as the climatic conditions are concerned.

Every year, a considerable number of $F$. sporotrichioides isolates were obtained from the analyzed 
rye heads with the symptoms of fusariosis. Earlier, this species was isolated from the heads of barley (Ki e c ana, 1994; Perkowski et al. 1997), wheat (Tóth , 1997) and oat panicles (M i e lniczuk, 2001). Fusarium sporotrichioides has been found to be the cause of chaff necrosis and leaf spot in the state of Minnesota (V a rg o and B a u m e r, 1986), changes in the colour and consistency of barley and oat kernels (Kiecana, 1994, Mielniczuk, 1999) as well as necrosis of roots and leaf sheath of oat seedlings (K i ecana and Kocyłak, 1999).

The species frequently isolated from the analyzed rye heads included $F$. poae. This fungus commonly occurred on oat panicles in the Lublin region (Kiecana and Perkowski, 1998; Kiecana et al. 2005). Under different cultivation conditions, $F$. poae is considered to be the cause of fusariosis of cereal heads in Europe (T óth, 1997; Thrane, 2001; M i e l n i c z u k, 2001), and in other continents (Tekauz et al. 2004; Muthomi et al. 2008).

Like in the case of other cereals, A. alternata was frequently observed on rye heads ( $\mathrm{K}$ i e c a n a , 1994; Mielniczuk, 2001; Muthomi et al. 2008).

Epicoccum nigrum, which was frequently isolated from rye kernels and chaff, was found to be the cause of wheat leaf spot (Goel and Gupta 1979 according to Ting and Reedler 1991).

The presence of the polyphagous species of $B$. cinerea on the heads was probably caused by the stimulating effect of pollen on the germination of spores, which made heads infection at the stage of anthesis possible. Earlier investigations of P o k a c k a (1987) concerning rye allow such an interpretation.

\section{REFERENCES}

Bottalico A., 1998. Fusarium disease of cereals: species complex and related mycotoxins profiles, in Europe. J. Plant Pathol. 80 (2): 85 - 103.

Bottalico A., Perrone G., 2002. Toxigenic Fusarium and mycotoxins associated with head blight in smallgrain cereals in Europe. Europ. J. Plant Pathol. 108: 611-624.

Burgess L., Liddel1 C., Summerell B. A., 1988. Laboratory Manual for Fusarium Research. Department of Plant Pathology and Agricultural Entomology, University of Sydney.

Chełkowski J., 1989. Formation of mycotoxins produced by Fusarium in heads of wheat, triticale and rye. [In]: Chełkowski J. (ed), Fusarium - Mycotoxins, Taxonomy and Pathogenicity: 63-84 Elsevier, Amsterdam, The Netherlands.

K i e c a n a I., 1986. Fuzarioza kłosów pszenżyta. / Fusariosis of triticale ears. Rocz. Nauk Roln., ser. E, 16 (2): 59-68.

Kiec ana I., 1988. Badania podatności kłosów pszenżyta na porażenie przez Fusarium spp. / Studies on the susceptibility of triticale ears to the infection by Fusarium spp. Rocz. Nauk Roln., ser. E, 18 (2): 17 - 41.

K i e c a n a I., 1994. Badania nad fuzariozą kłosów jęczmienia jarego (Hordeum vulgare L.) z uwzględnieniem podatności odmian i zawartości mikotoksyn w ziarnie. / Investigations on Fusarium head blight of spring barley (Hordeum vulgare L.) concerning the susceptibility of cultivars and mycotoxin accumulation in kernels. Seria Wydawnicza - Rozprawy Naukowe, AR, 161: 1- 49.

Kiecana I., Perkowski J., 1998. Zasiedlenie ziarna owsa (Avena sativa L.) przez toksynotwórcze grzyby Fusarium poae (Peck.) Wr. i Fusarium sporotrichioides Sherb. / Colonization of oat kernels by toxinogenic fungi Fusarium poae (Peck.) Wr. and Fusarium sporotrichioides Sherb. Zeszyty Naukowe AR w Krakowie, 333: $881-884$.

Kiecana I., Kocyłak E., 1999. Pathogenicity of Fusarium spp. on oat seedlings (Avena sativa L.). Plant Breed. and Seed Sci. 43 (1): 91 - 99.

Kiecana I., Mielniczuk E., Cegiełko M., Pszczółkowski P., 2003. Badania nad chorobami podsuszkowymi owsa (Avena sativa $\mathrm{L}$.) z uwzględnieniem temperatury i opadów. / Investigations on root and stem rot diseases of oat (Avena sativa $\mathrm{L}$.) with a special regard to temperature and rainfall. Acta Agrobot. 56 (12): 95-107.

Kiecana I., Mielniczuk E., Perkowski J., Goliński P., 2005. Porażenie wiech przez Fusarium poae (Peck) Wollenw. oraz zawartość mikotoksyn w ziarnie owsa. / Infection of panicles with Fusarium poae (Peck) Wollenw. and mycotoxin content in oat grain. Acta Agrobot. 58: 91-100.

Kiecana I., Cegiełko M., Mielniczuk E., 2009. Występowanie Fusarium spp. na życie ozimym (Secale cereale L.) i podatność różnych genotypów na porażenie przez $F$. avenaceum (Fr. ) Sacc. i $F$. culmorum (W. G. Sm.) Sacc. / The occurrence of Fusarium spp. on winter rye (Secale cereale L.) and susceptibility of different genotypes to infection with $F$. avenaceum ( $\mathrm{Fr}$.) Sacc. and F. culmorum (W.G.Sm.) Sacc. Biul. IHAR, 252: $151-161$.

Łacic ow a B., 1970. Badania szczepów Helminthosporium sorokinianum $(=H$. sativum) oraz odporności odmian jęczmienia jarego na ten czynnik chorobotwórczy. / Investigations on Helminthosporium sorokinianum $(=H$. sativum) strains and on the resistance of spring barley varieties to this pathogenic factor. Acta Mycol. VI. (2): $187-248$

Łacicowa B., Sułek-Pięta D., Wagner A., 1987. Grzyby z rodzaju Fusarium porażające kłosy pszenicy ozimej. / Fungi of the Fusarium genus infecting winter wheat ears. Zesz. Probl. Post. Nauk Roln. 307: 165-173.

Miedaner T., Borchardt D. C., Geiger H. H., 1993. Genetic analysis of inbred and their crosses for resistance to head blight (Fusarium culmorum, F. graminearum) in winter rye. Euphytica, 65: 123-133.

Miedaner T., Reinbrecht C., Lauber U., Schollenberger M., Geiger H. H., 2001. Effects of 
genotype-environment interaction on deoxynivalenol accumulation and resistance to Fusarium head blight in rye, triticale, and wheat. Plant Breeding, 120: 97 - 105.

Miedaner T., Schneider B., Geiger H.H., 2003. Deoxynivalenol (DON) content and Fusarium head blight resistance in segregating populations of winter rye and winter wheat. Crop Sci. 43: 519-526.

Mielniczuk E., 1999. Badania nad występowaniem fuzariozy wiech owsa (Avena sativa $\mathrm{L}$.) z uwzględnieniem podatności odmian i zawartości mikotoksyn w ziarnie. / praca doktorska, 1-77.

Mielniczuk E., 2001. The occurrence of Fusarium spp. on panicles of oat (Avena sativa L.). J. Plant Prot. Res. 41 (2): $173-180$.

Muthomi J. W., Ndung U. J., Gathumbi J. K., Mutitu F. W., Wagacha J. M., 2008. The occurrence of Fusarium species and mycotoxins in Kenyan wheat. Crop Protection, 27 (98): 1215-1219.

Nelson P. E., Toussoun T. A., Marasas W. F. O., 1983. Fusarium species. An ilustrated manual for identification. The Pennsylvania State University Press, University Park and London.

Panisson E., Reis E. M., Boller W., 2003. Quantificaçăo de danos causados pela Giberela em cereais de inverno na safra 2000, em Passo Fundo, RS (Assessment of damage caused by head blight in winter cereal crops in the 2000 season, in Passo Fundo countr, RS). Fitopatol. bras. 28 (2): 189-192.

Pałys E., Kiecana I., Kraska P., Mielniczuk E., 2004. Wpływ systemów uprawy roli oraz poziomów nawożenia i ochrony żyta ozimego na porażenie podstawy źdźbła przez grzyby chorobotwórcze. / The influence of tillage systems and fertilization and plant protection levels on winter rye stem base infection by pathogenic fungi. Progress in Plant Protection/ Postępy w Ochronie Roślin, 44 (2):1001-1003.

Parry D.W., Jenkinson P., McLeod L., 1995. Fusarium ear blight (scab) in small grain cereals-a review. Plant Pathol. 44: 207-238.

Perkowski J., Jeleń H., Kiecana I., Goliński P., 1997. Natural contamination of spring barley with group A trichothecene mycotoxins in South-Eastern Poland. Food Add. and Contam. 14 (4): 321 - 325.

Pokacka Z ., 1987. Badania nad mikoflorą ziarna żyta, roślin opryskiwanych i nie opryskiwanych fungicydami. / Investigations on the mycoflora of rye kernels from fungicide-treated and untreated plants. Prace Naukowe IOR 29 (1): 93 - 108.

Šrobarová A., Šliková S., Šudyová V., 2008. Diversity of the Fusarium species associated with head and seedling blight on wheat in Slovakia. Biologia (Bratislava), 63 (3): 332-337.

Tekauz A., McCallum B., Ames N., Mitchell Fetch J., 2004. Fusarium head blight of oat-current status in western Canada. Can. J. Plant Pathol. 26 (4): 473-479.
Thrane U., Adler A., Clasen P-E., Galvano F., Langseth W., Lew H., Logrieco A., Nielsen K. F., Ritieni A., 2004. Diversity in metabolite production by Fusarium langsethiae, Fusarium poae, and Fusarium sporotrichioides. Internat. J. Food Microbiol. 95: 257-266

Ting Z., Reedler R. D., 1991. Colonization of bean flowers by Epicoccum purpurascens. Phytopathology, 81: 774-778.

Tóth A., 1997. Dominance condition of Fusarium species occurring in winter wheat kernels in pest country. Cer. Res. Comm. 25 (3/2): 625-627.

Tottman D. R., 1987. The decimal code for the growth stages of cereals with illustrations. BCPC Publications Reprinted from the Ann. Applied Biol. 110. Occasional Publication, 4: 441 - 454.

Vančo B., Šliková S., Šudyová V., 2007. Influence of localities and winter wheat cultivars on deoxynivalenol accumulation and disease damage by Fusarium culmorum. Biologia (Bratislava), 62/1:62-66.

Vargo R. H., Baumer J. S., 1986. Fusarium sporotrichioides as a pathogen of spring wheat. Plant Dis. 70: 629-631.

Wakuliński W., Chełkowski J., 1993. Fusarium species causing scab of wheat, rye and triticale in Poland. Hod. Rośl. Aklim. 37 (4): 137-142.

$\mathrm{Xu}$ X. M., Nicholson P., Thomsett M. A. Simpson D., Cooke B. M., Doohan F. M., Brennan J., Monghan S., Moretti A., Mule G., Hornok L., Beki E., Tatnell J., Ritinei A., 2008. Relationship between the fungal complex causing Fusarium head blight of wheat and environmental conditions. Phytopathology, 98 (1): 69-78.

\section{Fuzarioza kłosów żyta ozimego (Secale cereale L.)}

\section{Streszczenie}

Badania nad fuzariozą kłosów żyta przeprowadzono w latach 2005-2007 na 10 polach produkcyjnych zlokalizowanych w okolicach Lublina. Procent kłosów żyta z objawami fuzariozy w latach 2005 - 2007 roku wynosił od 0 do 7.

Analiza mikologiczna ziarniaków i plew uzyskanych z kłosów żyta z objawami fuzariozy wykazała, że największym zagrożeniem dla kłosów tego zboża, były Fusarium avenaceum, Fusarium culmorum i Fusarium sporotrichioides. Z porażonych kłosów uzyskiwano także gatunki Fusarium poae oraz Fusarium crookwellense. Dominację w porażaniu kłosów żyta przez poszczególne gatunki Fusarium spp. determinowały warunki pogodowe. 
